\title{
Dynamics of $\sum \mathrm{CO}_{2}$ in a surficial sandy marine sediment: the role of chemoautotrophy
}

\author{
Uffe Thomsen, Erik Kristensen*
}

Institute of Biology, Odense University, Campusvej 55, DK-5230 Odense M, Denmark

\begin{abstract}
Net consumption and production of $\mathrm{CO}_{2}$ in the surface layers of a sandy marine sediment were examined with a depth resolution of $1 \mathrm{~mm}$. A transient state diagenetic model fitted to measured porewater profiles of total inorganic carbon $\left(\Sigma_{\mathrm{CO}}\right)$ in open incubated sediment plugs revealed 3 distinct zones. The first was an upper oxic/suboxic zone of 5 to $8 \mathrm{~mm}$ depth with high net $\Sigma \mathrm{CO}_{2}$ production rates ( 4910 to $5570 \mathrm{nmol} \mathrm{cm} \mathrm{cm}^{-3} \mathrm{~d}^{-1}$ ). The second zone $(8$ to $9 \mathrm{~mm}$ ) below the suboxic layer showed a net $\mathrm{CO}_{2}$ uptake $\left(161\right.$ to $191 \mathrm{nmol} \mathrm{cm}^{-3} \mathrm{~d}^{-1}$ ) which coincided with the zone of maximum ${ }^{14} \mathrm{C}$-labeled bicarbonate fixation $\left(R_{1}{ }^{14}\right.$ c processes probably involving sulfur species, since both $\mathrm{NO}_{3}$ and metal oxides are absent. The $\mathrm{CO}_{2}$ fixation processes were, however, dependent on supply of oxidation equivalent from above, since they were completely inhibited under anoxic conditions in the overlying water. A third zone, situated below $16 \mathrm{~mm}$ in the deepest reduced sediment, had low net production rates of $\sum \mathrm{CO}_{2}$ (55 to $\left.97 \mathrm{nmol} \mathrm{cm}^{-3} \mathrm{~d}^{-1}\right)$. The role of $\mathrm{S}_{2} \mathrm{O}_{3}{ }^{2-}$ in $\mathrm{CO}_{2}$ fixation was examined in completely anoxic and closed sediment incubations (jars). The presence of $0.5 \mathrm{mM} \mathrm{S}_{2} \mathrm{O}_{3}{ }^{2}$ did not induce higher $\mathrm{CO}_{2}$ fixation rates than $\mathrm{S}_{2} \mathrm{O}_{3}{ }^{2-}$-free controls. When thiosulfate was increased to $2 \mathrm{mM}$, a stimulation of $\mathrm{CO}_{2}$ fixation occurred, indicating chemoautotrophy by e.g. disproportionation. The fact that significant $\mathrm{CO}_{2}$ fixation also occurred initially in thiosulfate-free, anoxic control sediment indicated that hetero-/chemolithotrophic $\mathrm{CO}_{2}$ fixation may be higher in marine sediment than previously thought.
\end{abstract}

KEY WORDS: Mineralization - Carbon fixation - Diagenetic modelling - Sulfate reduction Thiosulfate Marine sediment

\section{INTRODUCTION}

Coastal marine sediments are supplied by organic carbon allochthonously via sedimentation or autochthonously via benthic micro- and macrophytes. Chemoautotrophic fixation of $\mathrm{CO}_{2}$ in sediments can also be considered an autochthonous source of highly labile organic matter (Fenchel \& Blackburn 1979). Howarth (1984) estimated that chemoautotrophic production consumed 3 to $6 \%$ and 10 to $18 \%$ of the heterotrophic $\mathrm{CO}_{2}$ production in 2 coastal sediments of low and high metabolic activity, although this may be an overestimation (Jørgensen 1988). Chemolithotrophic bacteria obtain energy by oxidizing inorganic substrates derived from anaerobic decomposition of

\footnotetext{
·Addressee for correspondence. E-mail: ebk@biology.ou.dk
}

photosynthetically produced organic material (Jørgensen 1989). Therefore, these bacteria are found in transitional environments where electron acceptors and reduced inorganic compounds are present simultaneously. One classic example is the extremely narrow $\mathrm{O}_{2}-\mathrm{H}_{2} \mathrm{~S}$ interface in chemoautotrophic Beggiatoa mats that oxidize sulfide at very high rates (Jørgensen \& Revsbech 1983, Nelson et al. 1986).

In coastal marine sediments, deficiency of total inorganic carbon $\left(\sum \mathrm{CO}_{2}\right)$ in discrete layers below the oxic surface has been ascribed to chemoautotrophic assimilation (Aller \& Yingst 1985, Kristensen \& Hansen 1995). The most likely electron acceptors for chemoautotrophy in the suboxic zone of these sediments are $\mathrm{Mn}^{4+}$ and $\mathrm{Fe}^{3+}$ (Howarth 1984, Aller \& Rude 1988). Sspecies like $\mathrm{S}_{2} \mathrm{O}_{3}{ }^{2-}$ and $\mathrm{SO}_{3}{ }^{2-}$ can be produced as intermediates in the chemoautotrophic catalyzed oxidation of $\mathrm{HS}^{-}$or $\mathrm{FeS}$ to $\mathrm{SO}_{4}{ }^{2-}$ by $\mathrm{MnO}_{2}$ (Aller \& Rude 1988, 
King 1990). Spontaneous oxidation of $\mathrm{HS}^{-}$by Fe-oxides can also produce $\mathrm{S}_{2} \mathrm{O}_{3}{ }^{2-}, \mathrm{SO}_{3}{ }^{2-}$, and $\mathrm{SO}_{4}{ }^{2-}$ (Dos Santos Afonso \& Stumm 1992). The complex of partially oxidized S-compounds may also by themselves be important for carbon dynamics in anaerobic sediments. The role of these compounds is supported by reports of autotrophic disproportionating and chemoautotrophic bacteria (Tuttle \& Jannasch 1973, 1977, Jørgensen et al. 1979, Kepkay \& Novitsky 1980, Bak \& Cypionka 1987, Bak \& Pfennig 1987, Thamdrup et al. 1993). The quantitative role of chemoautotrophic bacteria in marine ecosystems, however, is still not fully understood.

The aim of this study was to locate and quantify net rates of $\Sigma \mathrm{CO}_{2}$ production and consumption with a depth resolution of $1 \mathrm{~mm}$ in subsurface layers of open incubated organic-poor marine sediment. Estimates of net $\sum \mathrm{CO}_{2}$ consumption from profile modelling were compared with rates of gross uptake of ${ }^{14} \mathrm{C}$-labeled bicarbonate. Closed sediment incubations were used to evaluate the potential role of $\mathrm{S}_{2} \mathrm{O}_{3}{ }^{2-}$ for ${ }^{14} \mathrm{CO}_{2}$ incorporation under reduced conditions.

\section{MATERIALS AND METHODS}

Sediment sampling. Subtidal sediment was collected in June (plugexp 1), August (plugexp 3), and December (plugexp 2) 1994 from the shallow (0.2 to $0.6 \mathrm{~m}$ ) marine lagoon Fællesstrand, on the northeast coast of Fyn, Denmark. The sediment was homogeneous and consisted of well-sorted sand with a low content of silt and clay $(<0.5 \%)$. The organic content was low (losson-ignition $\sim 0.5 \%$ ), originating primarily from benthic diatoms. The macrophyte vegetation was poor in the area with the seagrass Ruppia maritima as the most abundant species. Benthic macrofauna were numerous with the polychaete Nereis diversicolor, the gastropod Hydrobia neglecta, and the crustacean Corophium volutator as the most common species. A detailed description of the area is given by Kristensen (1993).

On each sampling date surface sediment $(0$ to $5 \mathrm{~cm}$ ) was sieved through a $1 \mathrm{~mm}$ mesh in the field to remove benthic macrofauna. In the laboratory the sediment was further sieved through a $500 \mu \mathrm{m}$ mesh and stored at $5^{\circ} \mathrm{C}$ in a polyvinylchloride ( $\mathrm{PVC}$ ) container with $1 \mathrm{~cm}$ of overlying water until further use within $3 \mathrm{~d}$.

Plug experiments (plugexp). Of the 3 plug experiments conducted, plugexp 1 and 2 were aerobic while plugexp 3 consisted of both aerobic and anaerobic incubations. The sediment was homogenized by hand and placed in cylindrical plug holders, $5.5 \mathrm{~cm}$ high and $8.0 \mathrm{~cm}$ in diameter (Fig. 1). The sediment plugs were adjusted by a movable bottom to obtain a depth of $3 \mathrm{~cm}$ $(L)$, with the sediment surface flush with the upper

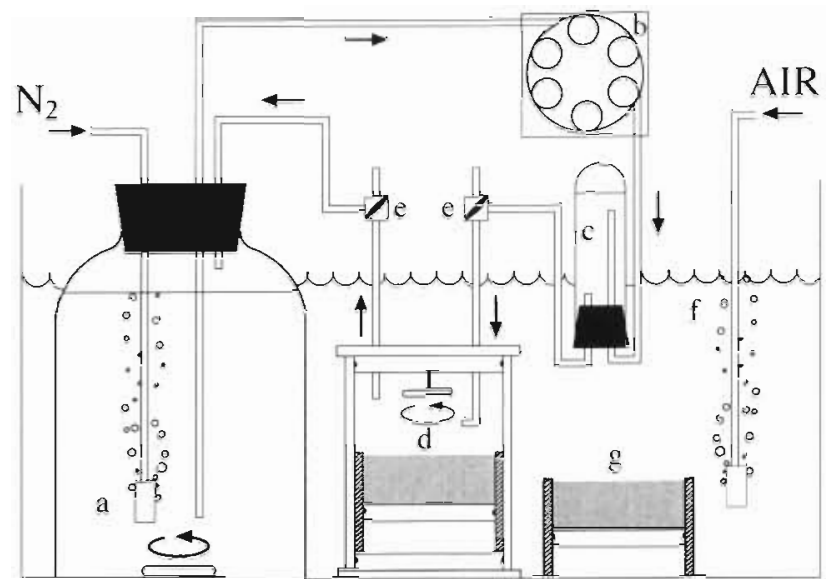

Fig 1 Schematic presentation of the experimental set-up used for anoxic and oxic plug incubations. a: stirred anoxic reservoir purged with $\mathrm{N}_{2}$; b: peristaltic pump; c: debubbler; $d$ : stirred anoxic plug chamber; e: sample valves; f: oxic aquarium stirred by a circulation pump and purged with air; $\mathrm{g}$ : sediment plug holder

edge of the plug holders. During each incubation temperature was $15^{\circ} \mathrm{C}$ and salinities were 18,27 , and $24 \%$ in plugexp 1,2, and 3 , respectively.

PIugexp 1 and 2: In each of plugexp 1 and 2,6 to 10 plugs were gently submerged into a darkened and aerated $300 \mathrm{l}$ reservoir. A submerged centrifugal pump provided continuous water circulation. The incubation time was 20 to $28 \mathrm{~d}$ with renewal of $1 / 6$ of the seawater every fourth day. Before a set of 3 preincubated plugs were sectioned, flux measurements on each were performed by incubation in circular plexiglass chambers $(11 \mathrm{~cm}$ diameter) with an effective volume of 1.25 l (i.e. corrected for plug volume). The chambers were closed with O-ring sealed lids that had inlet and outlet equipped with 3-way sampling valves and an adjustable stirring bar (Teflon-coated) receiving momentum from an external rotating magnet at $\sim 100 \mathrm{rpm}$. Stirring was kept below the resuspension level and a dye test confirmed the stirring efficiency. Three to four sampling routines were done over a total flux incubation time of 9 to $24 \mathrm{~h}$. Samples for $\mathrm{CO}_{2}$ were taken by $10 \mathrm{ml}$ glass syringes (Fortuna) and preserved by adding $0.2 \%$ saturated $\mathrm{HgCl}_{2}$. Analysis was done within $6 \mathrm{~h}$ by flow injection/diffusion cell analysis (Hall \& Aller 1992) on a Kontron HPLC (high-performance liquid chromatography) system with $30 \mathrm{mM} \mathrm{HCl}$ as carrier and $10 \mathrm{mM} \mathrm{NaOH}$ as receiver (precision $<2 \%$ ). Parallel samples were taken and analyzed for $\mathrm{O}_{2}$ by the standard Winkler technique (precision $<0.3 \%$ ). Fluxes (directly measured: $J_{\mathrm{DM}}$ ), were determined from the accumulation rate of $\Sigma \mathrm{CO}_{2}\left(C_{t}\right)$ over time $t$. $C_{t}$ was corrected for dilution of sample by compensation water. The correction was $<0.5 \%$. 
Subsequently, the plugs were cut into 1,2 , and $3 \mathrm{~mm}$ sections in the intervals $0-12,12-20$, and $20-26 \mathrm{~mm}$, respectively, for porewater extraction. During sectioning, a cylindrical collar with the same diameter as the plug holders and a height of $1 \mathrm{~mm}$ was placed on top of the holders. Plugs were then elevated within the holder by a screw-based piston with a $1 \mathrm{~mm}$ pitch. The sediment was pushed until the surface was flush with the upper edge of the collar. A steel plate with a thickness of $0.5 \mathrm{~mm}$ was used to cut off the sediment inside the collar The plugs were cut successively and each slice was transferred into a $20 \mathrm{ml}$ polystyrene (PS) vial. The screwcaps of the vials were penetrated in the circumference by a needle leaving a $0.5 \mathrm{~mm}$ hole. Before the vials were capped, a $0.45 \mu \mathrm{m}$ Millipore filter supported by a Whatman GF/C filter was placed inside each cap. All vials were then transferred bottom-up into centrifuge tubes and centrifuged for $10 \mathrm{~min}$ at $2200 \mathrm{rpm}(800 \times g)$. The extracted porewater was analyzed immediately for $\mathrm{pH}$ (plugexp 2) and $\Sigma \mathrm{CO}_{2}$ (plug$\exp 1$ and 2). Remaining porewater was stored at $-18^{\circ} \mathrm{C}$ for later analysis of either $\mathrm{NO}_{3}{ }^{-}$(plugexp 1) or $\mathrm{SO}_{4}^{2-}$ (plugexp 2).

Porewater $\mathrm{pH}$ was measured with a $\mathrm{pH}$-electrode (Orion, 81-03) and $\sum \mathrm{CO}_{2}$ was determined by flow injection/diffusion cell analysis after interfering sulfide had been precipitated with $100 \mu$ of $50 \%$ saturated $\mathrm{HgCl}_{2}$ per $900 \mu \mathrm{l}$ sample and removed by centrifugation at $14000 \mathrm{rpm}(13000 \times \mathrm{g})$ for $5 \mathrm{~min}$. Samples of $\mathrm{NO}_{3}{ }^{-}$were analyzed using the standard autoanalyzer method of Armstrong et al. (1967). $\mathrm{SO}_{4}{ }^{2-}$ was analyzed by Dionex ion chromatography using an AG4A precolumn and an IonPaC AS4A-SC anion column with a self-regenerating suppressor (ASRS-I). The eluent was carbonate $(1.8 \mathrm{mM})$-bicarbonate $(1.7 \mathrm{mM})$. Precision was better than $3 \%$.

Solid phase $\mathrm{Fe}$ (plugexp 1) was determined by $\mathrm{HCl}$ extractions according to Lovley \& Phillips (1987) with a slightly modified hydroxylamine hydrochloride reduction technique (Thamdrup et al. 1994). Three plugs were sectioned and handled in a glovebag with a $\mathrm{N}_{2}$ atmosphere. Each section was homogenized and subsamples $(\sim 1 \mathrm{~g})$ were extracted in $5 \mathrm{ml}$ of $0.5 \mathrm{~N} \mathrm{HCl}$ for $30 \mathrm{~min}$. After centrifugation the supernatant was analyzed spectrophotometrically for $\mathrm{HCl}$ extractable Fe(II) using the Ferrozine color reaction (Stookey 1970). Total extractable Fe [Fe(II) + Fe(III)] was analyzed similarly after hydroxylamine hydrochloride reduction of supernatant subsamples. The concentration of Fe(III) was calculated as the difference between total $\mathrm{Fe}$ and Fe(II) concentrations.

Plugexp 3: The oxic and anoxic preincubations in plugexp 3 were made simultaneously for $21 \mathrm{~d}$ (Fig. 1). Four aerobic plugs were incubated as mentioned above for plugexp 1 and 2. Four other plugs were preincubated under anoxic conditions in 4 plexiglass chambers $(11.5 \mathrm{~cm}$ high and $9.1 \mathrm{~cm}$ in diameter) that had a continuously recycled flow of anoxic water supplied from a $10 \mathrm{l} \mathrm{N}_{2}$ purged reservoir (renewed every fourth day). Bottom and top of the chambers were closed with O-ring sealed plexiglass lids. The flow of water through the chambers was maintained by a peristaltic pump (Ismatec, mp-ges) at a rate of 4.3 to $5.6 \mathrm{l}$ $\mathrm{d}^{-1}$. All tubing and connections were made of glass, PVC, or tygon. Frequent tests revealed that $\mathrm{O}_{2}$ was absent in the reservoir water. Water above the sediment $(390 \mathrm{ml})$ was stirred as described previously. Valves before the inlet and after the outlet in the sediment chambers were used for sampling of water for $\mathrm{CO}_{2}$ analysis.

After the preincubation period a short-term $\left[{ }^{14} \mathrm{C}\right] \mathrm{HCO}_{3}-\left({ }^{14} \mathrm{CO}_{2}\right)$ incubation was conducted. Oxic plugs were placed in chambers similar to those used for the anoxic sediment. The overlying water was removed, leaving a $1 \mathrm{~mm}$ water film above the sediment surface before 8 vertical injections of $25 \mu \mathrm{l}$ $\left[{ }^{14} \mathrm{C} \mathrm{HCO}_{3}^{-}\left(9 \mu \mathrm{Ci} \mathrm{ml}{ }^{-1}\right)\right.$ with a $250 \mu \mathrm{l}$ SGE syringe were applied to each plug (both oxic and anoxic). Care was taken to assure a homogeneous vertical distribution of tracer. Oxic plugs were incubated with air as headspace, while anoxic plug chambers were purged with $\mathrm{N}_{2}$ for $5 \mathrm{~min}$ before lid closure. After $2 \mathrm{~h}$ of acclimatization, anoxic and oxic plugs were sectioned and porewater extracted at approximately $16 \mathrm{~h}$ intervals over a $2 \mathrm{~d}$ period. Porewater and overlying water were preserved by adding $0.5 \mathrm{M} \mathrm{NaOH}$ to $\mathrm{pH}>12$ and stored in $20 \mathrm{ml}$ PS vials at $5^{\circ} \mathrm{C}$ for later analysis of ${ }^{14} \mathrm{CO}_{2}$. Fresh sediment subsamples $(\sim 0.5 \mathrm{~g})$ were acidified by adding $0.7 \mathrm{ml}$ of $0.5 \mathrm{M} \mathrm{HCl}$ and dried at $105^{\circ} \mathrm{C}$ for $24 \mathrm{~h}$ to remove dissolved and precipitated ${ }^{14} \mathrm{C}$ labeled inorganic carbon. The dried samples were then ground and analyzed for total organic C (TOC) and $N(T O N)$ and ${ }^{14} \mathrm{C}$-labeled TOC $\left(\left[{ }^{14} \mathrm{C}\right]\right.$ TOC $)$

Porewater and overlying water samples of 0.5 to $1 \mathrm{ml}$ were diluted with distilled water to a final volume of $7 \mathrm{ml}$. [ $\left.{ }^{14} \mathrm{C}\right] \mathrm{CO}_{2}$ was then separated by acidification with $0.5 \mathrm{ml}$ of $2 \mathrm{M} \mathrm{HCl}$ and trapped in $25 \%$ (vol/vol) ethanolamine in 2-ethoxyethanol after purging with air as a carrier gas (Andersen \& Kristensen 1992). TOC and TON subsamples were analyzed on a HewlettPackard 185B CHN-analyzer and $\left[{ }^{14} \mathrm{C}\right] \mathrm{CO}_{2}$ in the exhausted gas was trapped as mentioned above to obtain incorporated $\left[{ }^{14} \mathrm{C}\right] \mathrm{TOC}$ (Kristensen \& Andersen 1987). $\left[{ }^{14} \mathrm{C}\right] \mathrm{CO}_{2}$ trap samples $(7 \mathrm{ml}$ ) were mixed with $10 \mathrm{ml}$ Luma Safe Plus (Packard) scintillation liquid and counted on a Packard 2200CA Tri-Carb scintillation analyzer (liquid scintillation counting, LSC). The total carbon incorporation $\left(\mathrm{TOC}_{\mathrm{i}}\right.$ ) in each sample was calculated from incorporated $\left[{ }^{14} \mathrm{C}\right] \mathrm{TOC}$ and specific ${ }^{14} \mathrm{C}$ activity of porewater $\mathrm{CO}_{2}$. 
Independently incubated plugs were used for determination of porosity profiles, determined from wet density (weight of known volume) and water content (water loss after drying at $130^{\circ} \mathrm{C}$ for $6 \mathrm{~h}$ ).

Jar experiment (jarexp). A volume of $2250 \mathrm{ml}$ reduced anoxic sediment the same batch as used in plugexp 2) was homogenized under $N_{2}$. A subsample was taken for determination of porosity, as in the plugexp, before the sediment was split into 3 portions of $750 \mathrm{ml}$. To each portion was added $900 \mu \mathrm{l}$ of a $\left[{ }^{14} \mathrm{C}\right] \mathrm{HCO}_{3}^{-}$solution $\left(25 \mu \mathrm{Ci} \mathrm{ml}{ }^{-1}\right)$ under continuous mixing. Subsequently, $3.0 \mathrm{ml}$ of either 0, 50, or $200 \mathrm{mM}$ $\mathrm{S}_{2} \mathrm{O}_{3}{ }^{2-}$ solution was added to the 3 portions to obtain final concentrations of $\sim 0(C), 0.5 \mathrm{mM}(T 1 / 2)$ and $2 \mathrm{mM}$ (T2). After thoroughly mixing again the sediment from each of the 3 portions was transferred to either $10(\mathrm{C})$ or 20 (T1/2 and T2) $20 \mathrm{ml}$ acid-washed glass vials (borosilicate, Packard). The vials were filled completely allowing no headspace, closed with foil-lined screw caps, and sealed with tape. In order to assure completely anoxic conditions the vials were incubated. half-submerged bottom up in anoxic sediment. Incubation temperature was $15^{\circ} \mathrm{C}$.

Frequent sampling by sacrificing $1(C)$ or 2 (T1/2 and $T 2)$ vials were done during the first $2 \mathrm{~d}$ and once a week during the remaining $29 \mathrm{~d}$ experimental period. Fresh sediment subsamples $(\sim 0.5 \mathrm{~g})$ were taken for determination of $\mathrm{TOC}_{1}$ (as in plugexp 3 ). The vials were then centrifuged for porewater extraction through a GF/C filter (Whatman, $25 \mathrm{~mm}$ ) as described earlier. The porewater was subsequently filtered through a $0.2 \mu \mathrm{m}$ polycarbonate membrane filter (Whatman, $25 \mathrm{~mm}$ ). After determining the porewater $\mathrm{pH}, 1000 \mu \mathrm{l}$ subsamples were transferred to $1.5 \mathrm{ml}$ Eppendorf tubes, capped and stored at $5^{\circ} \mathrm{C}$ for less than $24 \mathrm{~h}$ before analysis for $\Sigma \mathrm{CO}_{2}$ (as in plugexp 1 and 2). Other $1000 \mu$ l subsamples were preserved with $0.5 \mathrm{M} \mathrm{NaOH}$ to $\mathrm{pH}>12$ and stored in $20 \mathrm{ml}$ PS vials at $5^{\circ} \mathrm{C}$ for later analysis of ${ }^{14} \mathrm{C}$-labeled dissolved inorganic $\left(\left[{ }^{14} \mathrm{C}\right] \mathrm{CO}_{2}\right)$ and organic $\left(\left[{ }^{14} \mathrm{C}\right] \mathrm{DOC}\right)$ carbon. Isola tion of $\left[{ }^{14} \mathrm{C} \mathrm{CO}_{2}\right.$ from porewater was performed as described in plugexp 3. In addition, the acidified and flushed porewater samples were radioassayed for $\left[{ }^{14} \mathrm{C}\right] \mathrm{DOC}$. Dissolved volatile organic compounds may have been lost by the flushing treatment, but they usually constitute only a minor part of the total DOC pool (Sugimura \& Suzuki 1988). The radioactivity was determined by addition of $10 \mathrm{ml}$ UItima Gold XR (Packard) scintillation liquid and counted by LSC as mentioned earlier. The total carbon incorporation in dissolved form $\left(\mathrm{DOC}_{\mathrm{i}}\right)$ was calculated from incorporated $\left[{ }^{14} \mathrm{C}\right] D O C$ and specific ${ }^{14} \mathrm{C}$ activity of $\mathrm{CO}_{2}$ in each sample. Remaining porewater ( 1.5 to $2 \mathrm{ml}$ ) was stored at $-18^{\circ} \mathrm{C}$ for later analysis of $\mathrm{SO}_{4}{ }^{2-}$ and $\mathrm{S}_{2} \mathrm{O}_{3}{ }^{2-}$. $\mathrm{SO}_{4}{ }^{2-}$ was analyzed as described in plugexp 2 and $\mathrm{S}_{2} \mathrm{O}_{3}{ }^{2-}$ was quantified colorimetrically after cyanolysis (Nor \& Tabatabai 1975)

The temporal variation in porewater solutes was described by least squares linear regressions and rates or ratios are presented as the slope with standard error of the coefficient (SE). Statistical comparisons were performed by either Student's t-test or analysis of covariance (ANCOVA) and multiple comparisons (Zar 1984).

\section{RESULTS}

\section{Sediment description}

There was a distinct colour zonation in oxic sediment plugs. The surface was covered by a patchy fluff layer indicating meiofauna activity (Aller \& Aller 1992). The upper $2 \mathrm{~mm}$ orange-brown zone was followed by a $8 \mathrm{~mm}$ grey zone. Below $1 \mathrm{~cm}$ depth, the sediment was greyish-black with a distinct sulfide odour. The anoxic plugs were, like the closed incubated sediment (jarexp), homogeneously greyish-black.

Porosity in the plugs ranged from 0.28 to 0.35 , with highest values in the uppermost and bottom layers. Depth averaged TOC and TON were $104 \pm 22$ and $9.3 \pm 1.5( \pm \mathrm{SD}, \mathrm{N}=60) \mu \mathrm{mol} \mathrm{g}^{-1}$ dry $w \mathrm{t}$, respectively, providing a $\mathrm{C}: \mathrm{N}$ ratio of 11 .

\section{Plugexp}

Sediment-water fluxes. Flux incubations showed a linear $\sum \mathrm{CO}_{2}$ concentration change with time $\left(\mathrm{r}^{2}=0.69\right.$ to 0.85 ), indicating a constant production rate. Shortterm flux incubations $(9 \mathrm{~h})$ in plugexp 1 provided a $\sum \mathrm{CO}_{2}$ flux of $25.0 \pm 3.3 \mathrm{mmol} \mathrm{m}^{-2} \mathrm{~d}^{-1}( \pm \mathrm{SE}, \mathrm{N}=3)$, but with poor precision $<50 \%$ due to insufficient analytical sensitivity. Precision in the long-term ( $24 \mathrm{~h}$ ) plugexp 2 was $<21 \%$ and the $\Sigma \mathrm{CO}_{2}$ flux was $35.3 \pm 4.0 \mathrm{mmol} \mathrm{m}^{-2}$ $\mathrm{d}^{-1}( \pm \mathrm{SE}, \mathrm{N}=3)$. The simultaneously measured $\mathrm{O}_{2} \mathrm{con}$ centration changes were highly linear $\left(r^{2} \geq 0.98\right)$, providing fluxes of $17.5 \pm 1.5$ and $19.4 \pm 0.7 \mathrm{mmol} \mathrm{m} \mathrm{m}^{-2} \mathrm{~d}^{-1}$ $( \pm \mathrm{SE}, \mathrm{N}=3)$ in plugexp 1 and 2 , respectively.

Porewater solutes. The general depth pattern of porewater $\mathrm{SCO}_{2}$ was similar in plugexp 1 and 2, although the actual shape of the profiles was different. Concentrations increased from -2.0 at the surface to $3.6 \mathrm{mM}$ at 23 to $26 \mathrm{~mm}$ depth with a subsurface minimum at 5 to 14 (plugexp 1) and 8 to 16 mm (plugexp 2) depth (Figs. 2A \& $3 \mathrm{~A}$ ), indicating a net production of $\Sigma \mathrm{CO}_{2}$ in the upper layers, net consumption in the midzone, and net production in the deepest part. A test showed that there was no significant difference between $\sum \mathrm{CO}_{2}$ profiles incubated for 22 and $29 \mathrm{~d}(\mathrm{p})$ 
0.05; randomized block ANOVA; multiple comparison), indicating that the systems were close to steady state. Calculations based on the concentration-independent reaction model according to Aller \& Mackin (1989) showed that steady state actually should be attained after $29 \mathrm{~d}$ with the $\Sigma \mathrm{CO}_{2}$ rates presented here (see 'Discussion').

Porewater $\mathrm{SO}_{4}{ }^{2-}$ in plugexp 2 increased from $24 \mathrm{mM}$ in the overlying water to $27 \mathrm{mM}$ at $4 \mathrm{~mm}$ depth. Below this depth the concentration decreased and reached $25 \mathrm{mM}$ in the deepest layers. $\mathrm{NO}_{3}{ }^{-}$decreased rapidly with depth from $200 \mu \mathrm{M}$ at the interface to $<10 \mu \mathrm{M}$ at $5-6 \mathrm{~mm}$ in plugexp 1, suggesting an intense consumption (Fig. 2C). The profile showed no real sign of net $\mathrm{NO}_{3}{ }^{-}$production, although nitrification must have occurred close to the sediment-water interface. The generally high $\mathrm{NO}_{3}{ }^{-}$concentration in the upper layers may have masked any production in this zone. The decrease in $\mathrm{pH}$ with depth in the sediment, although with bumps around 5 and $13 \mathrm{~mm}$, showed that acid producing processes dominated throughout the plugs in plugexp 2.

Particulate iron. Profiles of extractable Fe are shown in Fig. 2B (plugexp 1). Total $\mathrm{Fe}\left[\mathrm{Fe}(\mathrm{II})_{\mathrm{HCl}}+\mathrm{Fe}(\mathrm{III})_{\mathrm{HCl}}\right]$ was highest in the surface sediment $\left(2.6 \mu \mathrm{mol} \mathrm{g}{ }^{-1}\right.$ dry wt) where $\mathrm{Fe}(\mathrm{III})_{\mathrm{HCl}}$ constituted $84 \%$. There was a simultaneous decline in $\mathrm{Fe}(\mathrm{III})_{\mathrm{HCl}}$ and increase in Fe(II $)_{\mathrm{HCl}}$ in the 1 to $6 \mathrm{~mm}$ depth zone. From 12 to $13 \mathrm{~mm}$ depth the Fe(II $)_{\mathrm{HCl}}$ level increased abruptly from 1.3 to $1.7 \mu \mathrm{mol} \mathrm{g}{ }^{-1}$ dry wt, which coincided with the greyish to black colour transition. The lower boundary of the $\mathrm{Fe}(\mathrm{III})_{\mathrm{HCl}}$ and $\mathrm{NO}_{3}{ }^{-}$zones, which were almost identical $(5-6 \mathrm{~mm})$, defines the suboxic-anoxic transition (Froelich et al. 1979)

${ }^{14} \mathrm{CO}_{2}$ incorporation. Incorporation of ${ }^{14} \mathrm{CO}_{2}$ into $\mathrm{TOC}_{\mathrm{i}}\left(R_{\mathrm{TOC}}\right)$ was highly dependent on the presence of $\mathrm{O}_{2}$ in the overlying water (Fig. 4). Significant ${ }^{14} \mathrm{C}$ incorporation was distributed over a wide zone ( 5 to $18 \mathrm{~mm}$ ) in oxic plugs, whereas no significant ( $p>0.05$ ) incorporation was evident at any depth in anoxic plugs. The bell-shaped incorporation profile in the oxic incubation showed a maximum rate of $240 \mathrm{nmol} \mathrm{cm}^{-3} \mathrm{~d}^{-1}$ at $13 \mathrm{~mm}$ depth.

\section{Jarexp}

Porewater solutes. Accumulation of $\mathrm{SCO}_{2}$ showed a general 2-phase linear pattern in all treatments ( $p \leq 0.05)$, although not significant in $C(p=0.12)$. The transition between phase 1 and 2 occurred after about 55 h (Fig. 5). The

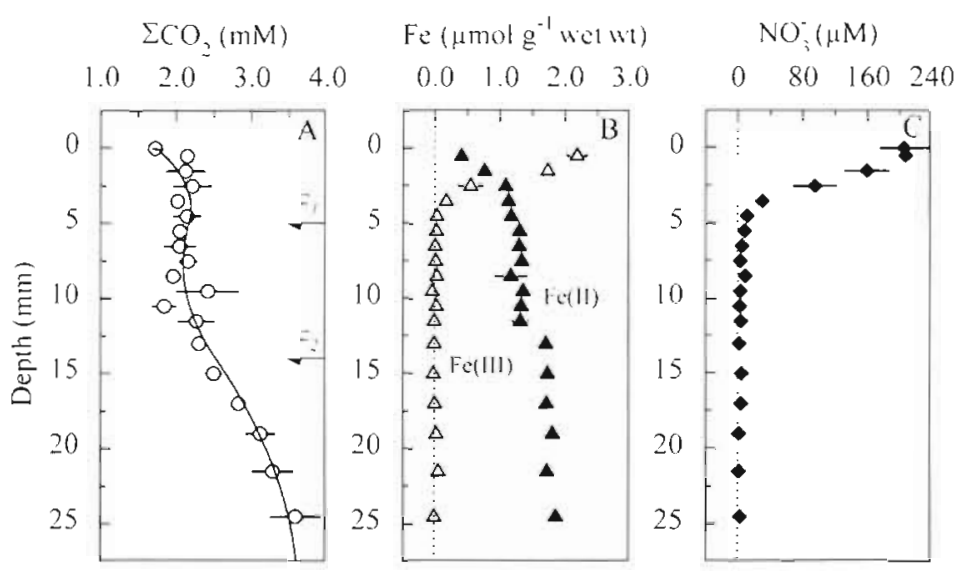

Fig. 2. Plug experiment (plugexp) 1 Vertical profiles of: (A) $\Sigma \mathrm{CO}_{2}$ i the solid line represents the best fit using the 3-layer diagenetic model (Eq. 1); boundaries are indicated by $z_{1}$ and $z_{2}$; (B) $\mathrm{HCl}$ extractable solid phase $\mathrm{Fe}(\mathrm{II})$ and $\mathrm{Fe}(\mathrm{III})$; and (C) $\mathrm{NO}_{3}{ }^{-}$, as a function of depth. Concentrations given as mean $\pm \mathrm{SE}(\mathrm{N}=3)$

addition of thiosulfate in $T 1 / 2$ and $T 2$ did not significantly $(p>0.05)$ stimulate net $\sum \mathrm{CO}_{2}$ production in the initial phase (phase 1), although the $C$ and $T 1 / 2$ net production rates of 530 and $514 \mathrm{nmol} \mathrm{cm}^{-3} \mathrm{~d}^{-1}$, respectively, were low compared with $T 2,800 \mathrm{nmol} \mathrm{cm}^{-3} \mathrm{~d}^{-1}$. Net rates of $\Sigma \mathrm{CO}_{2}$ production in phase 2 decreased 3 to 4 times compared with phase 1 and reached $173 \mathrm{nmol}$ $\mathrm{cm}^{-3} \mathrm{~d}^{-1}$ in $C, 175 \mathrm{nmol} \mathrm{cm} \mathrm{cm}^{-3} \mathrm{~d}^{-1}$ in $T 1 / 2$, and $203 \mathrm{nmol}$ $\mathrm{cm}^{-3} \mathrm{~d}^{-1}$ in $\mathrm{T} 2$.

Consumption of $\mathrm{SO}_{4}{ }^{2-}$ in $C$ and $T 1 / 2$ was rapid in phase 1 with rates of 1340 and $1170 \mathrm{nmol} \mathrm{cm}^{-3} \mathrm{~d}^{-1}$, respectively, but decreased dramatically in phase 2 to 142 and $115 \mathrm{nmol} \mathrm{cm}^{-3} \mathrm{~d}^{-1}$, respectively (Fig. 5). In $T 2$ the $\mathrm{SO}_{4}{ }^{2-}$ pattern was clearly affected by thiosulfate, leading to a slightly increasing $\mathrm{SO}_{4}{ }^{2-}$ concentration

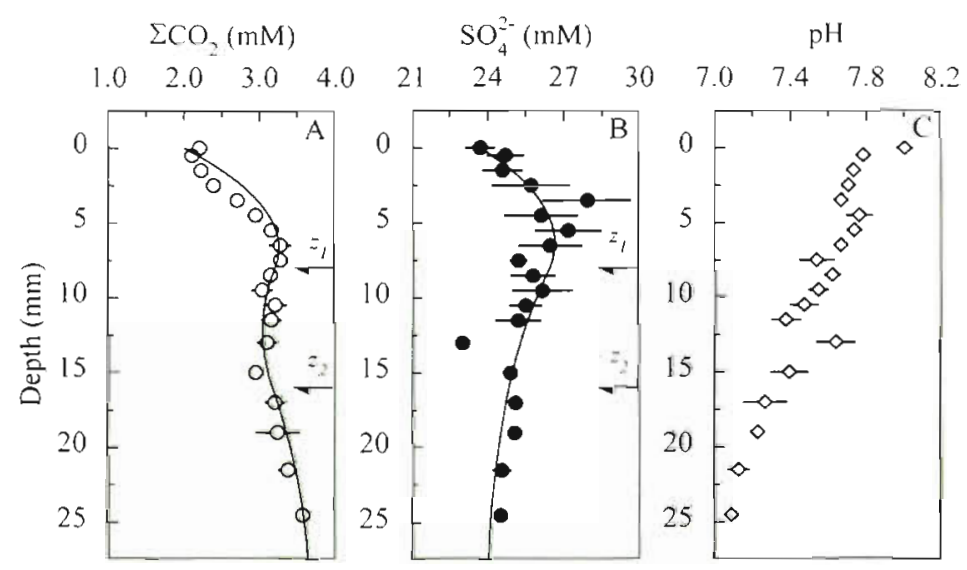

Fig. 3. Plugexp 2. Vertical profiles of (A) $\Sigma \mathrm{CO}_{2},(\mathrm{~B}) \mathrm{SO}_{4}{ }^{2-}$, and (C) pH. Solid lines in (A) and (B) represent the best fit using the 3-layer diagenetic model (Eq. 1); boundaries are indicated by $z_{1}$ and $z_{2}$. Values given as mean $\pm \mathrm{SE}(\mathrm{N}=3)$ 


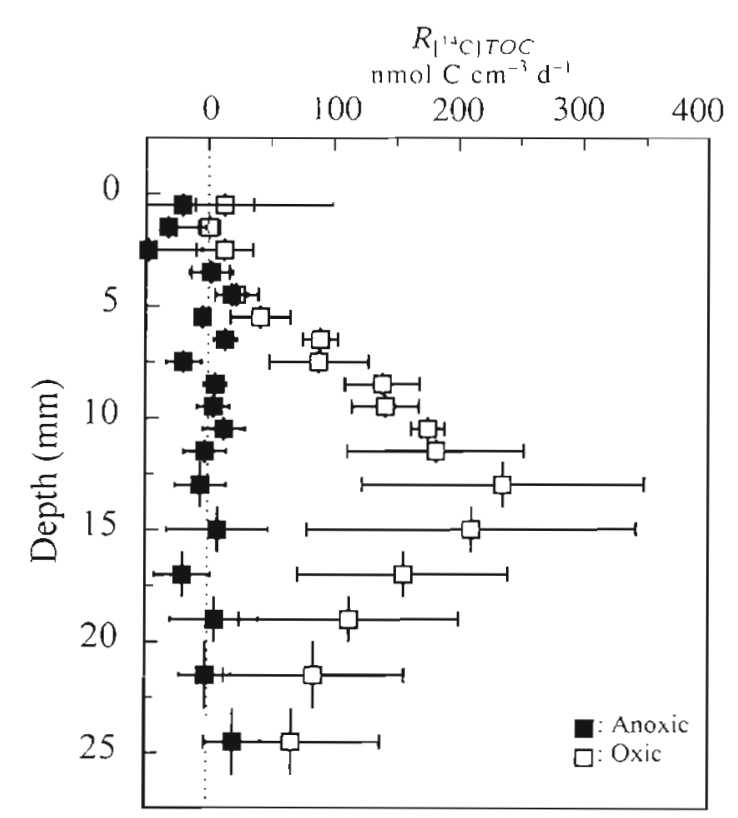

Fig. 4. Plugexp 3. Rates of $\mathrm{CO}_{2}$ incorporation into $\mathrm{TOC}_{1}\left(R_{\mathrm{TOC}}\right)$ as a function of depth in anoxic and oxic incubated cores. Data presented as the slope $\pm \mathrm{SE}$ of coefficient $(\mathrm{N}=4)$ from linear regression of time series incubations

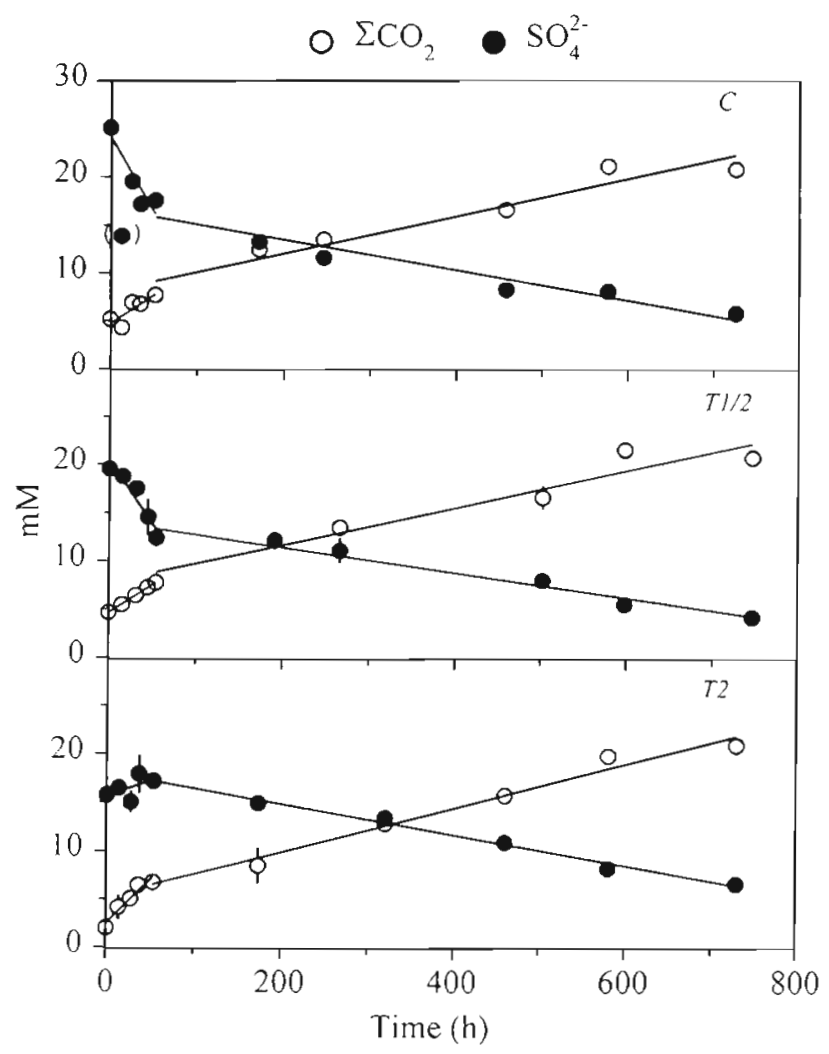

Fig. 5. Jar experiment (jarexp). Porewater $\mathrm{SCO}_{2}$ and $\mathrm{SO}_{4}{ }^{2-}$ of control (C), $0.5 \mathrm{mM} \mathrm{S}_{2} \mathrm{O}_{3}{ }^{2-}$ (T1/2), and $2 \mathrm{mM} \mathrm{S}_{2} \mathrm{O}_{3}{ }^{2-}$ (T2) jars as a function of time. $C$ is represented by single determination while $T 1 / 2$ and $T 2$ are mean \pm range $(N=2)$. Lines represent linear regressions of phase $1(<55 \mathrm{~h})$ and phase 2 ( $>55 \mathrm{~h})$, respectively
Table 1. Jar experiment (jarexp). C:S stolchiometry of net $\mathrm{SCO}_{2}$ production and net $\mathrm{SO}_{4}^{2-}$ reduction in phase 1 and 2 (see text). Values are given as slopes $\pm \mathrm{SE}(\mathrm{N})$ and correlation coefficients are presented as $r^{2}$

\begin{tabular}{|c|c|c|c|c|}
\hline & $\begin{array}{c}\text { Phase } 1 \\
\text { C:S }\end{array}$ & $r^{2}$ & $\begin{array}{c}\text { Phase } 2 \\
\text { C:S }\end{array}$ & $\mathrm{r}^{2}$ \\
\hline C & $0.26 \pm 0.09(4)$ & 0.83 & $1.17 \pm 0.17(6)$ & 0.92 \\
\hline$T 1 / 2$ & $0.37 \pm 0.06(10)$ & 0.84 & $1.40 \pm 0.17(12)$ & 0.86 \\
\hline$T 2$ & - & - & $1.40 \pm 0.10(12)$ & 0.96 \\
\hline
\end{tabular}

during the initial phase. $\mathrm{S}_{2} \mathrm{O}_{3}{ }^{2-}$ was consumed linearly $\left(\mathrm{r}^{2}=0.87\right)$ at a rate of $250 \mathrm{nmol} \mathrm{cm}{ }^{-3} \mathrm{~d}^{-1}$ during this phase (data not shown). Subsequently, the $\mathrm{SO}_{4}{ }^{2-}$ reduction $\left(141 \mathrm{nmol} \mathrm{cm}^{-3} \mathrm{~d}^{-1}\right)$ in phase 2 approached the level found in $C$ and $T 1 / 2$. At the end of phase 1 the $\mathrm{S}_{2} \mathrm{O}_{3}{ }^{2-}$ concentration in $T 2$ jars was close to the level found in $C$ jars $(<30 \mu \mathrm{M})$. Unfortunately, $\mathrm{S}_{2} \mathrm{O}_{3}{ }^{2-}$ samples from $T 1 / 2$ were lost.

Net $\mathrm{SO}_{4}{ }^{2-}$ reduction and net $\mathrm{\Sigma CO}_{2}$ production showed a good correlation in both phase 1 and 2 of $C$ and $T 1 / 2$ jars (C:S; Table 1). The C:S stoichiometry in phase 1 was significantly lower $(\mathrm{p}<0.01)$ than in phase 2 for $C$ and $T 1 / 2$. The added thiosulfate did not significantly $(\mathrm{p}>0.05)$ alter the C:S ratio in $T 1 / 2$ compared with $C$ in phase 1 . There was no significant $(p>0.05)$ C:S correlation in phase 1 of $T 2$ when based on $\mathrm{SO}_{4}{ }^{2-}$, but net $\mathrm{S}_{2} \mathrm{O}_{3}{ }^{2-}$ consumption and net $\Sigma \mathrm{CO}_{2}$ production showed a good correlation $\left(r^{2}=0.85\right)$, leading to a $\sum \mathrm{CO}_{2}: \mathrm{S}_{2} \mathrm{O}_{3}{ }^{2-}$ ratio of $2.85 \pm 0.42(\mathrm{~N}=10)$. All jars had similar C:S ratios $(p>0.05)$ in phase 2 .

${ }^{14} \mathrm{CO}_{2}$ incorporation. Incorporation of inorganic carbon in the jar experiment was evident from both $\mathrm{TOC}_{\mathrm{i}}$ and $\mathrm{DOC}_{1}$ pools (Fig. 6). ${ }^{14} \mathrm{CO}_{2}$ incorporation into $\mathrm{TOC}_{\mathrm{i}}$ was only determined until $60 \mathrm{~h}$ (phase 1), whereas incorporation into $\mathrm{DOC}_{\mathrm{i}}$ was followed throughout the entire $744 \mathrm{~h}$ incubation period. All jars showed a net $\mathrm{TOC}_{\mathrm{i}}$ increase until 35 to $45 \mathrm{~h}$. Between 45 and $60 \mathrm{~h}$. however, the $\mathrm{TOC}_{\mathrm{i}}$ inventory declined. Estimates of $R_{\text {TOC }}$ during the initial 35 to $45 \mathrm{~h}$ were similar in $C$ and $T 1 / 2$ (see Table 2), whereas $T 2$ had a 5 to 6 times

Table 2. Jarexp. $\mathrm{CO}_{2}$ incorporation rates calculated from linear regressions of time-dependent changes in $\mathrm{TOC}_{1}, R_{\mathrm{TOC}_{1}}$ and $R_{\mathrm{POC}}$ ( $<35$ to $45 \mathrm{~h}$ ). Values are given as slopes $\pm \mathrm{SE}(\mathrm{N})$ Correlation coefficients are assigned as $r^{2} \Delta$ indicates the average fraction $\left(R_{\mathrm{TOC}_{1}}-R_{\mathrm{POC}_{1}}\right) / R_{\mathrm{TOC}_{1}}$ in $\%$

\begin{tabular}{|cccccc|}
\hline & $\begin{array}{c}R_{\text {TOC }} \\
\left(\mathrm{nmol} \mathrm{cm}^{-3} \mathrm{~d}^{-1}\right)\end{array}$ & $\mathrm{r}^{2}$ & $\begin{array}{c}R_{\mathrm{POC}} \\
\left(\mathrm{nmol} \mathrm{cm}^{-3} \mathrm{~d}^{-1}\right)\end{array}$ & $\mathrm{r}^{2}$ & $\begin{array}{c}\Delta \\
(\%)\end{array}$ \\
\hline$C$ & $99 \pm 25(4)$ & 0.88 & $70 \pm 31(4)$ & 0.71 & 29 \\
$T 1 / 2$ & $87 \pm 14(8)$ & 0.86 & $77 \pm 13(8)$ & 0.85 & 11 \\
$T 2$ & $490 \pm 270(8)$ & 0.35 & $490 \pm 270(8)$ & 0.35 & 0 \\
\hline
\end{tabular}




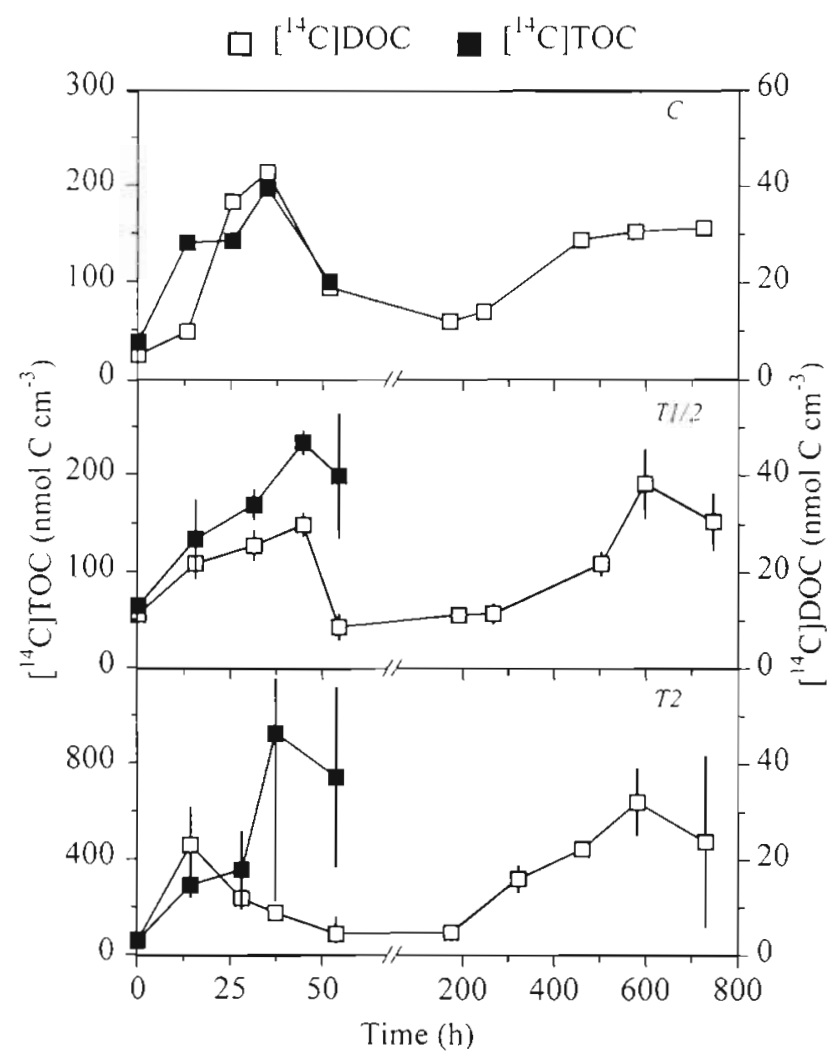

Fig. 6. Jarexp. Temporal pattern of $\mathrm{CO}_{2}$ incorporation into DOC $C_{1}$ and $\mathrm{TOC}_{1}$ in $C_{1} T 1 / 2$ and $T 2$ jars. $C$ is represented by single determination while $T 1 / 2$ and $T 2$ are mean \pm range $(N=2)$. Note the axis break on the abscissa and different scales of the ordinates

higher rate. $\mathrm{DOC}_{\mathrm{i}}$ peaked simultaneously or even earlier than $\mathrm{TOC}_{\mathrm{i}}$, reaching $43 \mathrm{nmol} \mathrm{C} \mathrm{cm}^{-3}$ at $35 \mathrm{~h}$ in $C$, $30 \mathrm{nmol} \mathrm{C} \mathrm{cm} \mathrm{Cm}^{-3}$ at $45 \mathrm{~h}$ in $T 1 / 2$, whereas a maximum of $23 \mathrm{nmol} \mathrm{C} \mathrm{cm}{ }^{-3}$ was attained as early as $14 \mathrm{~h}$ in $T 2$. The produced $\mathrm{DOC}_{i}$ accounted for about $10 \%$ of $\mathrm{TOC}_{1}$ in $\mathrm{C}$ and $T 1 / 2$ treatments, while $D O C_{i}$ constituted only 1 to $5 \%$ in $T 2$. The concentration of $\mathrm{DOC}_{1}$ reached a minimum of 4 to $19 \mathrm{nmol} \mathrm{C} \mathrm{cm}{ }^{-3}$ at the transition between phase 1 and 2 in all jars. Subsequently, the $\mathrm{DOC}_{\mathrm{i}}$ concentration was constant until $200 \mathrm{~h}$ followed by an increase in all jars to a level of $-30 \mathrm{nmol} \mathrm{C} \mathrm{cm}{ }^{-3}$.

\section{DISCUSSION}

\section{Subsurface carbon cycling}

Mineralization of organic matter produces $\mathrm{\Sigma CO}_{2}$ at the expense of terminal electron acceptors and therefore $\Sigma \mathrm{CO}_{2}$ accumulates with depth in sediments. When autotrophic microbial and other $\mathrm{CO}_{2}$ consuming processes are present, profiles may locally be deflected (Aller \& Yingst 1985, Kristensen \& Hansen 1995). The boundaries between production and/or consumption rates can be defined from convex-concave transitions or marked differences in curvature of profiles. The $\sum \mathrm{CO}_{2}$ and $\mathrm{SO}_{4}{ }^{2-}$ profiles measured in the present plug experiments indicate that reactions were distinctively different in at least 3 depth zones: an upper $\mathrm{CO}_{2}$ and $\mathrm{SO}_{4}{ }^{2-}$ production zone, a middle $\mathrm{CO}_{2}$ and $\mathrm{SO}_{4}{ }^{2-}$ consumption zone, and a lower $\mathrm{CO}_{2}$ production and $\mathrm{SO}_{4}{ }^{2-}$ consumption zone (Figs. $2 \mathrm{~A} \& 3 \mathrm{~A}, \mathrm{~B}$ ).

Reaction rates of $\sum \mathrm{CO}_{2}$ and $\mathrm{SO}_{4}{ }^{2-}$ in non-bioturbated sediments can be estimated from measured porewater profiles. Assuming that profiles are the result of reaction and diffusion processes, i.e. neglecting sedimentation, compaction, and externally impressed flow, the distribution of any solute, $C_{x, t}$, can be described by the 1-dimensional diagenetic equation (Berner 1980):

$$
\frac{\partial C}{\partial t}=\frac{D_{\mathrm{s}}}{1+K}\left(\frac{\partial^{2} C}{\partial x^{2}}\right)+\frac{R}{1+K}
$$

where $t=$ time, $x=$ depth into the sediment, $K=$ adsorption coefficient, $D_{\mathrm{s}}=$ molecular diffusion coefficient in sediment, and $R=$ net reaction rate of solute.

In the present plugexp, a 3 -layer case is assigned to the diffusion-reaction model by separating the sediment column into an upper zone $1\left(0<x<z_{1}\right)$, middle zone $2\left(z_{1}<x<z_{2}\right)$, and lower zone $3\left(z_{2}<x<L\right)$. The reaction rates and diffusion coefficients are assumed constant within each zone. The adsorption coefficient $K$ for $\sum \mathrm{CO}_{2}$ [almost entirely $\mathrm{HCO}_{3}{ }^{-}$at the $\mathrm{pH} 7.5 \pm 0.3$ $( \pm \mathrm{SD})]$ and $\mathrm{SO}_{4}{ }^{2-}$ is assumed to be 0 . The sediment diffusion coefficient $D_{\mathrm{s}}$ is derived from the free solution diffusion coefficient, $D_{0}$, by correction for tortuosity by the empirical relation for sandy sediments $D_{\mathrm{s}} \approx \phi D_{0}(\mathrm{Li}$ \& Gregory 1974, Ullman \& Aller 1982), where $\phi$ is the average porosity in the zone of interest.

By applying the appropriate conditions (time $T_{i}$ depth $n$ and time increment $\delta T_{i}$ initial porewater concentration $C_{1 n t}$ i overlying water concentration $C_{T}$; depth of the zones $z_{1}, z_{2}, L$; and molecular diffusion coefficients in each zone $D_{\mathrm{s} 1}, D_{\mathrm{s} 2}$, and $D_{\mathrm{s} 3}$ ), the 3 reaction rates $R_{1}, R_{2}$, and $R_{3}$ can be deduced by solving Eq. (1) with the following initial and boundary conditions:

$$
\begin{aligned}
& \text { 1. } t=0, C=C_{\text {nnt }}, 0<x<L \\
& \text { 2. } t>0, C=C_{T}, x=0 \\
& \text { 3. } \partial C / \partial x=0, x=L
\end{aligned}
$$

Reaction rates were estimated by solving Eq. (1) using the implicit Crank-Nicolson numerical method. Every time step $(\delta T)$ until time $T$ involves the solution of a tridiagonal matrix with $n$ vertical depth increment entries by Gaussian elimination (Crank 1975, Vemuri \& Karplus 1981). The transient state model is widely applicable because exact information about initial conditions and reaction time does not necessitate steadystate assumptions. By assigning $z_{1}$ and $z_{2}$ as the depths of transition between the 3 zones mentioned above, 
Table 3. Plug experiments (plugexp) 1. and 2. Parameters used in the 3-layer diagenetic model (Eq 1 ) for best fit $\mathrm{ZCO}_{2}$ and $\mathrm{SO}_{4}{ }^{2-}$ profiles (Figs. 2A \& 3A, B) $z_{1}, z_{2}$ : depths of zone borders; $D_{s 1}, D_{52}, D_{3,3}$ : estimated sediment diffusion coefficients in the 3 zones; $C_{\text {init }}$ : initial porewater concentration; $C_{T}$ : overlying water concentration; $R_{1}, R_{2}, R_{3}$ : estimated volume specific rates. Positive rates indicate production

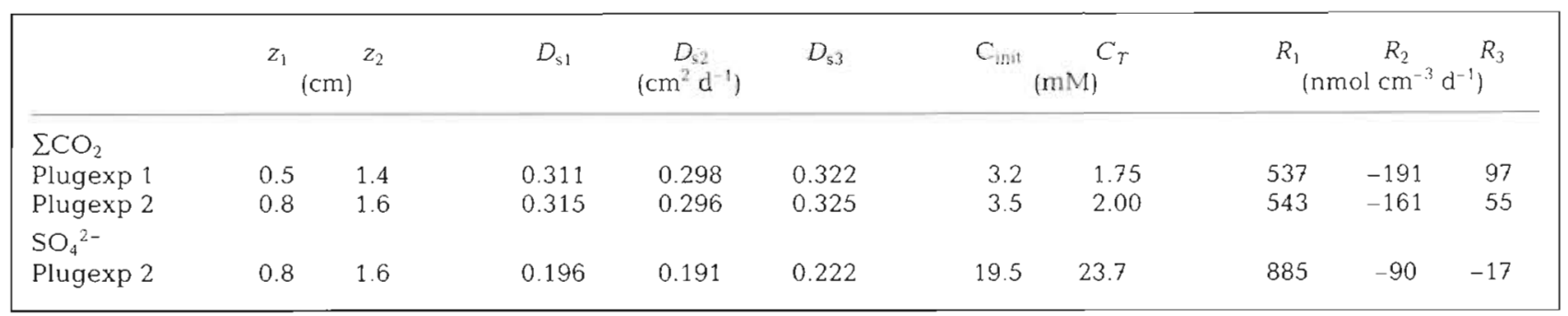

reaction rates in each zone $(R)$ were approximated from the visually best fit to each of the measured porewater profiles. Parameters used in the 3-layer diagenetic model are shown in Table 3.

The model-estimated profiles were in good agreement with the measured data, except for a slight overestimation at 1 to $5 \mathrm{~mm}$ depth in plugexp 2 (Fig. 3A, B). The concave bend in the upper $4 \mathrm{~mm}$ of $\Sigma \mathrm{CO}_{2}$ and $\mathrm{SO}_{4}{ }^{2-}$ profiles in plugexp 2 (Fig. $3 \mathrm{~A}, \mathrm{~B}$ ) suggested that enhanced transport of solutes occurred in this part of the sediment. Accordingly, the depth-integrated $\mathrm{CO}_{2}$ production based on porewater modelling $\left(J_{\Sigma \mathrm{R}}^{*}\right)$ was 10 times lower than the directly measured $\mathrm{CO}_{2}$ flux $\left(J_{\mathrm{DM}}\right.$; Table 4). Further, the diffusive flux can be estimated from Fick's first law by linear regression of the steepest concentration gradient in the surface sediment by (Berner 1980):

$$
J_{\nabla}=-\phi D_{\mathrm{s}}\left(\frac{\partial C}{\partial \mathrm{x}}\right)
$$

where $J_{\nabla}$ and $J_{\dot{\nabla}}$ were 9 to 13 times lower than $J_{\text {DM }}$ (Table 4 ). $J_{D M}$ was, despite the limited thickness $(3 \mathrm{~cm}$ ) of the sediment plugs, within the range previously reported for Fællesstrand sediment (Kristensen et al. 1992, Kristensen \& Hansen 1995). The rates may, however, be slightly overestimated due to bacterial contribution in the water phase and along chamber walls.

Table 4. Plugexp 1 and 2. Measured and estimated net fluxes of $\sum \mathrm{CO}_{2} . J_{\mathrm{DN}}$ : directly measured flux. Values represent average $\pm \mathrm{SE}(\mathrm{N})$; $J_{\nabla}$ : diffusion-estimated $\mathrm{CO}_{2}$ flux (Eq. 2) based on $\sum \mathrm{CO}_{2}$ profiles; $J_{\dot{v}}$ : diffusion-estimated $\mathrm{CO}_{2}$ flux (Eq. 2) based on Eq. (1) profiles; $J_{\mathrm{VNO}_{3}}$ : diffusion-estimated $\mathrm{CO}_{2}$ flux (Eq. 2) based on $\mathrm{NO}_{3}$ profiles using a $5 / 4$ conversion factor; $J_{\Sigma_{R}}$ : depthintegrated production rate estimated from diagenetic modelling (Eq. 1)

\begin{tabular}{|c|c|c|c|c|c|}
\hline \multirow[b]{2}{*}{ Plugexp 1} & \multicolumn{3}{|c|}{$J_{\nabla} \underset{\left(\mathrm{mmol} \mathrm{m}^{-2} \mathrm{~d}^{-1}\right)}{J_{\dot{r}}}$} & \multirow{2}{*}{$\begin{array}{c}J_{\nabla \mathrm{NO}_{3}}- \\
1.07^{(1-4)}\end{array}$} & \multirow{2}{*}{$\begin{array}{l}J_{\Sigma R} \\
2.40\end{array}$} \\
\hline & $25.0 \pm 3.3(3)$ & $2.33^{a(0-2)}$ & $2.41^{a(0-1)}$ & & \\
\hline Plugexp 2 & $35.3 \pm 4.0(3)$ & $2.67^{a(3-5)}$ & $3.90^{a(0-1)}$ & - & 3.53 \\
\hline
\end{tabular}

The apparent deficit between $J_{\mathrm{DM}}$ and the profile estimates can be explained by (1) $D_{\mathrm{s}}$ is underestimated in the upper few millimeters due to meiofaunal activity (Aller \& Aller 1992); (2) stirring during flux incubation significantly decreased the diffusive boundary layer. Further, stirring introduced pressure gradients that induced advective flushing of porewater solutes (Huettel \& Gust 1992, Glud et al. 1995, 1996). By the diffusion analogy, convective transport processes can simply be incorporated into the diffusion-reaction model (Eq. 1) as an effective transport coefficient $\left(\bar{D}_{s}\right)$ according to:

$$
\bar{D}_{\mathrm{s}}=D_{\mathrm{s}} \times J_{\mathrm{DM}} / J_{\dot{\nabla}}
$$

Assuming that advection is restricted to zone 1 and here discretely distributed with depth and horizontally uniform, $\bar{D}_{\mathrm{s} 1}$ equals 3.23 and $2.85 \mathrm{~cm}^{2} \mathrm{~d}^{-1}$ (plugexp 1 and 2). Hence, reaction rates estimated by Eq. (1) may be significantly underestimated in proportion to the enhancement of the transport coefficient. Using $\bar{D}_{\mathrm{s} 1}$ in Eq. (1), $\Sigma \mathrm{CO}_{2}$ reaction rates of 5570 and $4910 \mathrm{nmol} \mathrm{cm}^{-3} \mathrm{~d}^{-1}$ are obtained in the upper zone 1 of plugexp 1 and 2 , respectively, which are 60 to 90 times higher than zone 3 .

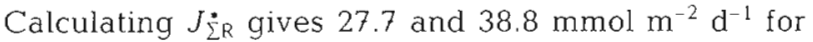
plugexp 1 and 2 respectively, which for obvious reasons are in good agreement with $J_{D M}$. Similarly, a net $\mathrm{SO}_{4}{ }^{2-}$ production rate of $8010 \mathrm{nmol} \mathrm{cm} \mathrm{cm}^{-3} \mathrm{~d}^{-1}$ is obtained in zone 1 of plugexp 2. However, porewater flow induced by pressure gradients decreases strongly with depth and also varies horizontally; accordingly, a higher degree of variation in $\bar{D}_{s}$ is expected within the upper few millimeters of the sediment.

The electron acceptors Fe(III) and $\mathrm{NO}_{3}$ were both consumed in zone 1 and may here be important for the heterotrophic oxidation of organic carbon (Fig. 2B, C; Sorensen \& Jørgensen 1987, Canfield et al. 1993a). This is in accordance with previous reports on coexistence of these and other respiratory processes (e.g Kerner 
1993, Brandes \& Devol 1995). Denitrification estimated from the steepest $\mathrm{NO}_{3}{ }^{-}$concentration gradient (Eq. 2) and converted to $\mathrm{CO}_{2}$ production (e.g. Seitzinger et al. 1980 ) is shown in Table 4 . Correcting $J_{\mathrm{VNO}_{3}}$ for enhanced solute transport using $\bar{D}_{\mathrm{s}}$ reveals a $\mathrm{CO}_{2}$ production of $10.86 \mathrm{mmol} \mathrm{m} \mathrm{m}^{-2} \mathrm{~d}^{-1}$. Thus, denitrification appeared to account for $-40 \%$ of the heterotrophic $\mathrm{CO}_{2}$ production, but part of the $\mathrm{NO}_{3}$ consumption in the deeper parts of the suboxic zone may be coupled to chemical or chemolithotrophic oxidation of reduced sulfur compounds (e.g. Sørensen et al. 1979, Jørgensen \& Sørensen 1985, Sørensen \& Jørgensen 1987, Canfield et al. 1993b). As a result, $\mathrm{SO}_{4}{ }^{2}$ is produced in the upper zone 1 (Fig. 3B, Table 3), although $\mathrm{SO}_{4}{ }^{2-}$ reduction and concomitant $\mathrm{SCO}_{2}$ production may proceed simultaneously,

Plugexp 2 and 3 suggested that the middle zone 2 , in addition to the consumption of $\mathrm{CO}_{2}$, was characterized by high rates of sulfate reduction. Hence, sulfide for chemolitho(auto)trophic bacteria seems available in this sediment despite the small height $(L)$. Both the net $\mathrm{CO}_{2}$ uptake estimated from the diffusion-reaction model in zone 2 and gross ${ }^{14} \mathrm{C}$ uptake showed extensive and almost similar rates (Fig. 4, Table 3), which indicated that transport of solutes here is strictly diffusional. The ${ }^{14} \mathrm{CO}_{2}$ incorporation rates are comparable to these of Enoksson \& Samuelsson (1987) in sediments of the Gullmar fjord (Sweden). The maximum $\mathrm{CO}_{2}$ fixation rate observed in the anoxic environment below the suboxic zone only in sediment underlying oxic water substantiated that incorporation of $\mathrm{CO}_{2}$ is strongly dependent on the presence of oxygen (Kepkay \& Novitsky 1980). The high $\mathrm{CO}_{2}$ fixation rate below the suboxic zone can therefore not be explained by heterotrophic assimilation, but rather by chemoautotrophic and mixotrophic incorporation. These 2 biologically driven $\mathrm{CO}_{2}$ fixation processes cannot be distinguished from each other based on ${ }^{14} \mathrm{CO}_{2}$ uptake alone and are here simply designated as chemoautotrophic activity. Since our ${ }^{24} \mathrm{CO}_{2}$ incorporation data in the oxic/suboxic zone (Fig. 4) were rather low compared with the deeper layers, $\mathrm{CO}_{2}$ fixation by chemoautotrophic oxidation of e.g. $\mathrm{NH}_{4}{ }^{+}$and $\mathrm{HS}^{-}$were of limited importance (Kepkay \& Novitsky 1980). Furthermore, anaerobic chemolithotrophic processes utilizing $\mathrm{NO}_{3}{ }^{-}$as electron acceptor are not likely to involve significant autotrophic $\mathrm{CO}_{2}$ fixation (Aller 1994, Mulder et al. 1995). Chemoautotrophic $\mathrm{CO}_{2}$ fixation (estimated from ${ }^{14} \mathrm{CO}_{2}$ fixation and $J_{\mathrm{DM}}$ ) was equivalent to $8-11 \%$ of total $\mathrm{CO}_{2}$ efflux from plugs. This is comparable to the estimates of Howarth (1984) based on sulfate reduction and total respiration rates of coastal sandy sediments. Based on a net $\mathrm{CO}_{2}$ uptake of $161 \mathrm{nmol} \mathrm{cm}^{-3} \mathrm{~d}^{-1}$ (plugexp 2; Table 3) and a gross $\mathrm{CO}_{2}$ uptake of $180 \mathrm{nmol} \mathrm{cm}^{-3} \mathrm{~d}^{-1}$ (plugexp 3) in the middle zone, the $\mathrm{CO}_{2}$ produced by sulfate reducing bacteria (SRB) was only $19 \mathrm{nmol} \mathrm{cm}^{-3} \mathrm{~d}^{-1}$ The high net $\mathrm{SO}_{4}{ }^{2-}$ reduction rate, but low gross $\mathrm{CO}_{2}$ production rate in zone 2 , suggested that $\mathrm{H}_{2}$ could be an important substrate for chemolithoautotrophic SRB. Accordingly, Novelli et al. (1988) generally found maximum rates of $\mathrm{H}_{2}$ production in the upper $3 \mathrm{~cm}$ of various coastal sediments. However, the $\mathrm{SO}_{4}{ }^{2-}$ profile reflected a complex sulfur dynamics (Fig. 3B) and a higher degree of variation with depth than described by the 3-layer model.

\section{Role of $\mathrm{H}_{2}$ and $\mathrm{S}_{2} \mathrm{O}_{3}{ }^{2-}$}

The 2 phase temporal pattern of $\mathrm{SCO}_{2}$ and $\mathrm{SO}_{4}{ }^{2-}$ in jars indicated a change in substrate availability for SRB. A similar rapid initial $\mathrm{SO}_{4}{ }^{2-}$ decrease in sediment enclosures was reported by Goldhaber et al. (1977). Aller \& Yingst (1980) suggested that variations in sulfate reduction following sediment mixing are due to excessive short-term substrate supply to microbial populations depleted for a specific substrate in the unmixed case. Depending on the type of substrate made available, the $\mathrm{C}: \mathrm{S}$ ratio may vary. The examples given below illustrate the variability in $\mathrm{C}: \mathrm{S}$ ratios of important metabolic processes involving $\mathrm{SO}_{4}{ }^{2-} \mathrm{com}-$ monly found in marine sediments (e.g. Laanbroek \& Pfennig 1981, Sørensen et al. 1981, Widdel 1988):

$$
\begin{aligned}
& \text { Acetate: } \\
& \quad \mathrm{CH}_{3} \mathrm{COO}^{-}+\mathrm{SO}_{4}{ }^{2-} \stackrel{\mathrm{C} \cdot \mathrm{S}=2}{\longrightarrow} 2 \mathrm{HCO}_{3}{ }^{-}+\mathrm{HS}^{-} \\
& \text {Propionate: } \\
& \begin{array}{r}
4 \mathrm{CH}_{3} \mathrm{CH}_{2} \mathrm{COO}^{-}+3 \mathrm{SO}_{4}{ }^{2-} \stackrel{\mathrm{CS}=4 / 3}{\longrightarrow} 4 \mathrm{CH}_{3} \mathrm{COO}^{-}+ \\
4 \mathrm{HCO}_{3}^{-}+3 \mathrm{HS}^{-}+\mathrm{H}^{+}
\end{array} \\
& \begin{array}{l}
\text { Hydrogen: } \\
\mathrm{H}_{2}+\mathrm{SO}_{4}{ }^{2-}+\mathrm{H}^{+} \stackrel{\mathrm{CS}=0}{\longrightarrow} 4 \mathrm{H}_{2} \mathrm{O}+\mathrm{HS}^{-}
\end{array}
\end{aligned}
$$

The rapid $\mathrm{SO}_{4}{ }^{2-}$ consumption and relatively slower $\Sigma \mathrm{CO}_{2}$ evolution in phase 1 with a $\mathrm{C}: \mathrm{S} \approx 0.26$ to $0.37(\mathrm{C}$ and $T 1 / 2$ ) indicate that $\mathrm{H}_{2}$ may be an important substrate used by SRB (Eq. 6). As $\mathrm{H}_{2}$ does not usually accumulate in sediments, an initial supply of $\mathrm{H}_{2}$ in phase 1 could be related to mixing-induced enhancement of $\mathrm{H}_{2}$ production by fermentation processes. Several species of SRB have been reported to grow by autotrophic or mixotrophic metabolism with $\mathrm{H}_{2}$ as the key electron donor (e.g. Badziong et al. 1978, 1979, Klemps et al. 1985, Widdel 1988). The ${ }^{14} \mathrm{CO}_{2}$ incorporation rate in unamended sediment (C) was relatively high compared with the $R_{\text {TOC }_{1}}=0$ obtained in the deep layers of anaerobic plug incubation, plugexp 3 , which also supports the contention that $\mathrm{H}_{2}$ utilization by SRB in phase 1 is an important electron donor for chemoautotrophy. But the $\mathrm{CO}_{2}$ fixation did not severely affect the $\mathrm{\Sigma} \mathrm{CO}_{2}$ production deficit, i.e. low C:S ratio, as carbon incorporation was only 12 to $15 \%$ of net $\mathrm{CO}_{2}$ production 


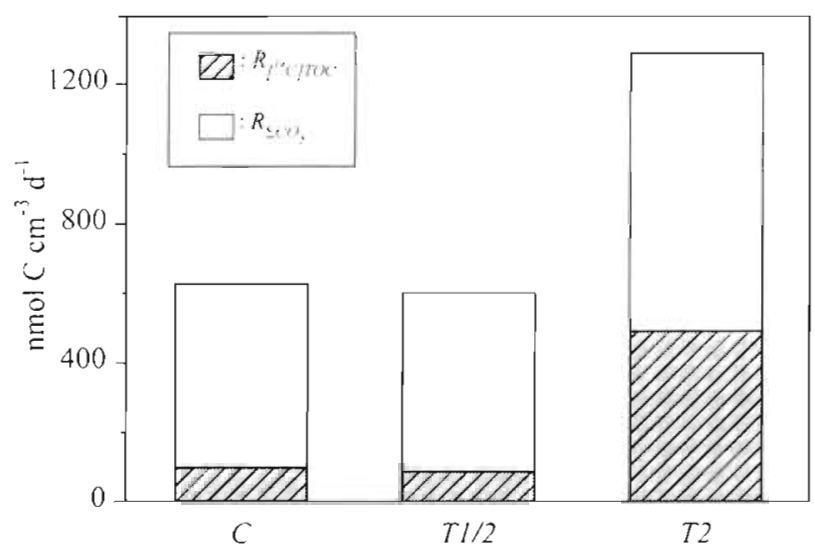

Fig. 7. Jarexp. Average gross $\Sigma \mathrm{CO}_{2}$ production calculated as the sum of $R_{\mathrm{T} \cap \mathrm{C}_{2}}$ and net $\Sigma \mathrm{CO}_{2}$ production $\left(R_{\mathrm{\Sigma CO}_{2}}\right)$

(Fig. 7). The similarity in C:S ratios in phase 2 among the 3 jar treatments indicated that the influence of $\mathrm{S}_{2} \mathrm{O}_{3}{ }^{2-}$ had diminished and that substrate availability had normalized. All C:S ratios in this phase were, however, still significantly lower $(p<0.001)$ than the theoretical C:S ratio of 2 for SRB using e.g. acetate as obtained in long-term jar incubations for 59 to $230 \mathrm{~d}$ (Burdige 1991, Kristensen \& Hansen 1995). Low C:S ratios may indicate that $\mathrm{SRB}$ oxidize organic carbon incompletely by e.g. the reaction shown in Eq. (5) or continues to fix $\mathrm{CO}_{2}$ driven by the reaction shown in Eq. (6).

The dependence of $\mathrm{CO}_{2}$ fixation in reduced sediment on the presence of $\mathrm{O}_{2}$ in the overlying water can be related to chemoautotrophic disproportionation of thiosulfate that has been produced by oxidation of sulfide in the suboxic layers (Fossing \& Jørgensen 1990). The addition of $0.5 \mathrm{mM} \mathrm{S}_{2} \mathrm{O}_{3}{ }^{2-}$, which is well above control $(C)$ level $<30 \mu \mathrm{M}$, did not induce any excessive $\mathrm{CO}_{2}$ fixation. But in $\mathrm{T} 2$ jars the $2 \mathrm{mM} \mathrm{S}_{2} \mathrm{O}_{3}{ }^{2-}$ pool caused a 5 times increase in ${ }^{14} \mathrm{CO}_{2}$ incorporation while gross $\mathrm{CO}_{2}$ production doubled (Fig. 7), which indicated that both chemoautotrophic and hetero-/chemolithotrophic processes can be stimulated by thiosulfate (Tuttle \& Jannasch 1977). The stimulation was probably due to $\mathrm{S}_{2} \mathrm{O}_{3}{ }^{2-}$ disproportionation and facultatively autotrophic growth by SRB (Bak \& Cypionka 1987) or replacement of $\mathrm{SO}_{4}{ }^{2-}$ in the $\mathrm{H}_{2}$-consuming reaction shown in Eq. (6) by $\mathrm{S}_{2} \mathrm{O}_{3}{ }^{2-}$ with concomitant assimilation of ${ }^{14} \mathrm{CO}_{2}$ (Badziong \& Thauer 1978). Net $\mathrm{SO}_{4}{ }^{2-}$ consumption during phase 1 in T2 treatments was competitively inhibited by $\mathrm{S}_{2} \mathrm{O}_{3}{ }^{2-}$ due to preferential consumption of thiosulfate by SRB (Postgate 1984. Widdel 1988) and production of $\mathrm{SO}_{4}{ }^{2-}$ from $\mathrm{S}_{2} \mathrm{O}_{3}{ }^{2-}$ may occur by disproportionation and oxidation (Jørgensen 1990, Elsgaard \& Jørgensen 1992).

The quantitative role of $\mathrm{DOC}_{\mathrm{i}}$ in jars was generally low and decreased in the sequence: $C>T 1 / 2>T 2$ (Table 2), implying that the presence of $\mathrm{S}_{2} \mathrm{O}_{3}{ }^{2-}$ caused a reduction in $\mathrm{DOC}_{\mathrm{i}}$ production or increase in $\mathrm{DOC}$ consumption. The positive correlation between $\mathrm{S}_{2} \mathrm{O}_{3}{ }^{2-}$ additions and net production of $\mathrm{POC}_{1}$, on the other hand, substantiated that $\mathrm{S}_{2} \mathrm{O}_{3}{ }^{2-}$ can be responsible for ${ }^{14} \mathrm{CO}_{2}$ incorporation into bacterial biomass. The wider $\mathrm{CO}_{2}$ fixation zone observed in plugexp $3\left({ }^{14} \mathrm{CO}_{2}\right.$ assay) than in plugexp 1 and 2 (porewater model) can be explained by the presence of mobile $D O C_{i}$ that have dispersed the spatial distribution of estimated $R_{\mathrm{TOC}_{1}}$ in plugexp 3 due to vertical diffusion and subsequent adsorption or biological uptake of $\mathrm{DOC}_{\mathrm{i}}$ in layers without $\mathrm{CO}_{2}$ fixation. The gradual increase of $\mathrm{DOC}_{\mathrm{i}}$ during phase $2\left(<2 \mathrm{nmol} \mathrm{cm}^{-3} \mathrm{~d}^{-1}\right)$ suggested a continued $\mathrm{CO}_{2}$ fixation or formation of refractory DOC from the old POC pool.

More work is required, however, to fully clucidate the relative role of autotrophic $\mathrm{S}_{2} \mathrm{O}_{3}{ }^{2-}$ oxidation/ disproportionation and $\mathrm{H}_{2}$ oxidation with respect to carbon dynamics in sub-suboxic sediment layers.

\section{CONCLUSIONS}

The present study provided evidence for a significant autochthonous primary production in a subsurface sandy sediment. The strong dependence of inorganic carbon uptake on the presence of oxygen in the overlying water, despite the fact that incorporation was located in totally anoxic sediment layers, suggested a coupling between oxic/suboxic and reduced sediment. A distinct 2 phase $\sum \mathrm{CO}_{2}$ and $\mathrm{SO}_{4}{ }^{2-}$ pattern with a low $C: S$ ratio in the initial phase ( 2 d) of the jarexp indicated that $\mathrm{H}_{2}$ could be an important electron donor for chemoautotrophic SRB. Hence, $\mathrm{H}_{2}$ consumption by SRB might be important in the zone of $\mathrm{CO}_{2}$ fixation, as $\mathrm{C}: \mathrm{S}$ attained a similar value here. The presence of high concentrations of $\mathrm{S}_{2} \mathrm{O}_{3}{ }^{2-}(2 \mathrm{mM}$, jarexp) stimulated both hetero-/chemolithotrophic activity and autotrophic $\mathrm{CO}_{2}$ fixation. Accordingly, very intense production rates of thiosulfate should prevail in the suboxic layers to support significant autotrophic $\mathrm{CO}_{2}$ fixation in anoxic layers below by e.g. thiosulfate disproportionation.

Acknowledgements. We thank Hanne Brandt and Ove Larsen for technical assistance in the laboratory and the Ecology Group at the Institute of Biology for valuable discussions. Furthermore, we thank T H. Blackburn and R. N. Glud for helpful suggestions and constructive criticism of the manuscript

\section{LITERATURE CITED}

Aller RC (1994) The sedimentary Mn cycle in Long Island sound: its role as intermediate oxidant and the influence of bioturbation, $\mathrm{O}_{2}$ and $\mathrm{C}_{\mathrm{org}}$ flux on diagenetic reaction balances. J Mar Res 52:259-295 
Aller RC, Aller JY (1992) Meiofauna and solute transport in marine muds. Limnol Oceanogr 37:1018-1033

Aller RC, Mackin JE (1989) Open-incubation, diffusion methods for measuring solute reaction rates in sediments. J Mar Res 47:411-440

Aller RC, Rude PD (1988) Complete oxidation of solid phase sulfides by manganese and bacteria in anoxic marine sediments. Geochim Cosmochim Acta 52:751-765

Aller RC, Yingst JY (1980) Relationships between microbial distibutions and the anaerobic decomposition of organic matter in surface sediments of Long Island Sound, USA. Mar Biol 56:29-42

Aller RC, Yingst JY (1985) Effects of the marine deposit-feeders Heteromastus filiformis (polychaeta), Macoma baltica (bivalvia), and Tellina texana (bivalvia) on averaged sedimentary solute transport, reaction rates, and microbial distributions. J Mar Res 43:615-645

Andersen FØ, Kristensen E (1992) The importance of benthic macrofauna in decomposition of microalgae in a coastal marine sediment. Limnol Oceanogr 37:1392-1403

Armstrong FAJ, Stearns CR, Strickland JDH (1967) The measurement of upwelling and subsequent biological processes by means of the Technicon autoanalyzer and associated equipment. Deep Sea Res 14:381-389

Badziong W, Ditter B, Thauer RK (1979) Acetate and carbon dioxide assimilation by Desulfovibrio vulgaris (Marburg), growing on hydrogen and sulfate as sole energy source. Arch Microbiol 123:301-305

Badziong W, Thauer RK (1978) Growth yields and growth rates of Desulfovibrio vulgaris (Marburg) growing on hydrogen plus sulfate and hydrogen plus thiosulfate as the sole energy sources. Arch Microbiol 117:209-214

Badziong W, Thauer RK, Zeikus JG (1978) Isolation and characterization of Desulfovibrio growing on hydrogen plus sulfate as the sole energy source. Arch Microbiol 116: $41-49$

Bak F, Cypionka H (1987) A novel type of energy metabolism involving fermentation of inorganic sulphur compounds. Nature 326:891-892

Bak F, Pfennig N (1987) Chemolithotrophic growth of Desulfovibrio sulfodismutans $\mathrm{sp}$. nov. by disproportionation of inorganic sulfur compounds. Arch Microbiol 147:184-189

Berner RA (1980) Early diagenesis, a theoretical approach. Princeton University Press, Princeton, NJ

Brandes JA, Devol AH (1995) Simultanous nitrate and oxygen respiration in coastal sediments: evidence for discrete diagenesis. J Mar Res 53:771-797

Burdige DJ (1991) The kinetics of organic matter mineralization in anoxic marine sediments. J Mar Res 49:727-761

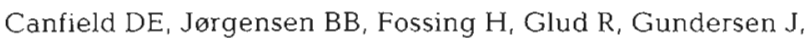
Ramsing NB, Thamdrup B, Hansen JW, Nielsen LP, Hall POJ (1993a) Pathways of organic carbon oxidation in three continental margin sediments. Mar Geol 113:27-40

Canfield DE, Thamdrup B, Hansen JW (1993b) The anaerobic degradation of organic matter in Danish coastal sediments: iron reduction, manganese reduction, and sulfate reduction. Geochim Cosmochim Acta 57:3867-3883

Crank J (1975) The mathematics of diffusion. Clarendon Press, Oxford

Dos Santos Afonso M, Stumm W (1992) The reductive dissolution of iron(III) (hydr)oxides by hydrogen sulfide. Langmuir 8:1671-1676

Elsgaard L, Jørgensen BB (1992) Anoxic transformations of radiolabeled hydrogen sulfide in marine and freshwater sediments. Geochim Cosmochim Acta 56:2425-2435

Enoksson V, Samuelsson MO (1987) Nitrification and dissimilatory ammonium production and their effects on nitrogen flux over the sediment-water interface in bioturbated coastal sediments. Mar Ecol Prog Ser 36:181-189

Fenchel T, Blackburn TH (1979) Bacteria and mineral cyclıng. Academic Press Inc, London

Fossing H, Jorgensen BB (1990) Oxidation and reduction of radiolabeled inorganic sulfur compounds in an estuarine sediment, Kysing Fjord, Denmark. Geochim Cosmochum Acta $54: 2731-2742$

Froelıch PN, Klinkhammer GP, Bender ML, Luedtke NA, Heath GR, Cullen D, Dauphin P, Hammond D, Hartman B, Maynard V (1979) Early oxidation of organic matter in pelagic sediments of the eastern equatorial Atlantic: suboxic diagenesis. Geochim Cosmochum Acta 43: $1075-1090$

Glud RN, Forster S, Huettel M (1996) Influence of radial pressure gradients on solute exchange in stirred benthic chambers. Mar Ecol Prog Ser 141:303-311

Glud RN, Gundersen JK, Revsbech NP, Jørgensen BB, Huettel $M$ (1995) Calibration and performance of the stirred flux chamber from the benthic lander Elinor. Deep Sea Res 42:1029-1042

Goldhaber MB, Aller RC, Cochran JK, Rosenfeld JK, Martens CS, Berner RA (1977) Sulfate reduction, diffusion, and bioturbation in Long Island Sound sediments: report of the FOAM group. Am J Sci 277:193-237

Hall POJ, Aller RC (1992) Rapid, small-volume, flow injection analysis for $\mathrm{TCO}_{2}$ and $\mathrm{NH}_{4}{ }^{*}$ in marine and freshwaters. Limnol Oceanogr 37:1113-1119

Howarth RW (1984) The ecological significance of sulfur in the energy dynamics of salt marsh and coastal marine sediments. Biogeochemistry 1:5-27

Huettel M, Gust G (1992) Impact of bioroughness on interfacial solute exchange in permeable sediments. Mar Ecol Prog Ser 89:253-267

Jørgensen BB (1988) Ecology of the sulphur cycle: oxidative pathways in sediments. Symp Soc Gen Microbiol 42:31-63

Jorgensen BB (1989) Biogeochemistry of chemoautotrophic bacteria. In: Schlegel HG, Bowien B (eds) Autotrophic bacteria. Science Tech Publishers, Madison, WI, p $117-146$

Jorgensen BB (1990) The sulfur cycle of freshwater sediments: role of thiosulfate. Limnol Oceanogr 35:1329-1342

Jørgensen BB, Kuenen JG, Cohen Y (1979) Microbial transformation of sulfur compounds in a stratified lake (Solar Lake, Sinai). Limnol Oceanogr 24:799-822

Jørgensen BB, Revsbech NP (1983) Colorless sulfur bateria, Beggiatoa spp. and Thiovolum spp. in $\mathrm{O}_{2}$ and $\mathrm{H}_{2} \mathrm{~S}$ microgradients. Appl Environ Microbiol 45:1261-1.270

Jørgensen BB, Sørensen J (1985) Seasonal cycles of $\mathrm{O}_{2}, \mathrm{NO}_{3}$ and $\mathrm{SO}_{4}{ }^{2-}$ reduction in estuarine sediments: the significance of an $\mathrm{NO}_{3}{ }^{-}$reduction maximum in spring. Mar Ecol Prog Ser 24:65-74

Kepkay PE, Novitsky JA (1980) Microbial control of organic carbon in marine sediments: coupled chemoautotrophy and heterotrophy. Mar Biol 55:261-266

Kerner M (1993) Coupling of microbial fermentation and respiration processes in an intertidal mudflat of the Elbe estuary. Limnol Oceanogr 38:314-330

King GM (1990) Effects of added manganic and ferric oxides on sulfate reduction and sulfide oxidation in intertidal sediments. FEMS Microbiol Ecol 73:131-138

Klemps R, Cypionka H, Widdel F, Pfennig N (1985) Growth with hydrogen, and further physiological characteristics of Desulfotomaculum species. Arch Microbiol 143:203-208

Kristensen E (1993) Seasonal variations in benthic community metabolism and nitrogen dynamics in a shallow, organicpoor Danish lagoon. Estuar Coast Shelf Sci 36:565-586 
Kristensen E, Andersen F $\varnothing$ (1987) Determination of organic carbon in marine sediments: a comparison of two CHN. analyzer methods. J Exp Mar Biol Ecol 109:15-23

Kristensen $E$, Andersen FØ, Blackburn TH (1992) Effects of benthic macrofauna and temperature on degradation of macroalgal detritus: the fate of organic carbon. Limnol Oceanogr 37:1404-1419

Kristensen $E_{1}$ Hansen K (1995) Decay of plant detritus in organic-poor marine sediment: production rates and stoichiometry of dissolved C and $\mathrm{N}$ compounds. J Mar Res 53: $1-28$

Laanbroek HJ, Pfennig N (1981) Oxidation of short-chain fatty acids by sulfate-reducing bacteria in freshwater and in marine sediments. Arch Microbiol 128:330-335

Li YH, Gregory S (1974) Diffusion of ions in sea water and in deep-sea sediments. Geochim Cosmochim Acta 38: 703-714

Lovley DR, Phillips EJP (1987) Rapid assay for microbially reducible ferric iron in aquatic sediments. Appl Environ Microbiol 53:1536-1540

Mulder A, van der Graaf AA, Robertson LA, Kuenen JG (1995) Anarobic ammonium oxidation discovered in a denitrifying fluidized bed reactor. FEMS Microbiol Ecol 16:177-184

Nelson DC, Jørgensen BB, Revsbech NP (1986) Growth pattern of a chemoautotrophic Beggiatoa sp. in oxygensulfide microgradients. Appl Environ Microbiol 52: $225-233$

Nor YM, Tabatabai MA (1975) Colorimetric determination of microgram quantities of thiosulfate and tetrathionate. Anal Lett 8:537-547

Novelli PC, Michelson AR, Scranton MI, Banta GT, Hobbie JE, Howarth RW (1988) Hydrogen and acetate cycling in two sulfate-reducing sediments: Buzzards Bay and Town Cove, Mass. Geochim Cosmochim Acta 52:2477-2486

Postgate JR (1984) The sulphate-reducing bacteria. Press Syndicate of the University of Cambridge, Cambridge

Seitzinger SP (1980) Denitrification and $\mathrm{N}_{2} \mathrm{O}$ production in near-shore marine sediments. Geochim Cosmochim Acta $44: 1853-1860$

Responsible Subject Editor: T. H. Blackburn, Aarhus, Denmark
Sørensen J, Jørgensen BB (1987) Early diagenesis in sediments from Danish coastal waters: microbial activity and Mn-Fe-S geochemistry. Geochim Cosmochin Acta 51:1583-1590

Sarensen .I, Jargensen 8B, Revsbech NP (1979) A comparison of oxygen, nitrate, and sulfate respiration in coastal marine sediments. Microb Ecol 5:105-115

Sørensen J, Christensen D, Jørgensen BB (1981) Volatile fatty acids and hydrogen as substrates for sulfate-reducing bacteria in anaerobic marine sediment. Appl Environ Microbiol 42:5-11

Stookey LL (1970) Ferrozine - a new spectrophotometric reagent for iron. Anal Chem 42:779-782

Sugimura Y, Suzuki Y (1988) A high-temperature catalytic oxidation method for determination of non-volatile dissolved organic carbon in seawater by direct injection of a liquid sample. Mar Chem 24:105-131

Thamdrup B, Finster K, Hansen JW, Bak F (1993) Bacterial disproportionation of elemental sulfur coupled to chemical reduction of iron or manganese. Appl Environ Microbiol 59:101-108

Thamdrup B, Fossing $\mathrm{H}$, Jørgensen BB (1994) Manganese, iron, and sulfur cycling in a coastal marine sediment (Aarhus Bay, Denmark). Geochim Cosmochim Acta 58: $5115-5129$

Tuttle JH, Jannasch HW (1973) Sulfide- and thiosulfide-oxidizing bacteria in anoxic marine basins. Mar Biol 20:64-70

Tuttle JH, Jannasch HW (1977) Thiosulfate stimulation of microbial dark assimilation of carbon dioxide in shallow marine waters. Microb Ecol 4:9-25

Ullman WJ, Aller RC (1982) Diffusion coefficients in nearshore marine sediments. Limnol Oceanogr 27:552-556

Vemuri V, Karplus WJ (1981) Digital computer treatment of partial differential equations. Prentice-Hall, Englewood Cliffs, NJ

Widdel $F$ (1988) Microbiology and ecology of sulfate- and sulfur-reducing bacteria. In: Zehnder AJB (ed) Biology of anaerobic bacteria. John Wiley \& Sons, New York, p $469-585$

Zar JH (1984) Biostatistical analysis. Prentice-Hall, Englewood Cliffs, NJ

Manuscript first received: May 29, 1996

Revised version accepted: January 3, 1997 